\title{
DETERMINATION OF EQUIVALENT CIRCUIT PARAMETERS OF INDUCTION MOTORS BY USING HEURISTIC ALGORITHMS
}

\author{
${ }^{1}$ Murat SELEK, ${ }^{2}$ Hakan TERZIOĞLUU \\ 1,2Selcuk University, Vocational School Of Technical Sciences, Selcuklu, Konya, TURKEY \\ ${ }^{1}$ mselek@selcuk.edu.tr, 2hterzioglu@selcuk.edu.tr
}

(Geliş/Received: 16.02.2017; Kabul/Accepted in Revised Form: 10.03.2017)

\begin{abstract}
Induction motors (IMs) are commonly used in industry due to the fact that they are simple, economic, durable, maintenance-free and they can run in every environmental conditions. Non-linear model and time varying parameters of IMs make it quite difficult to develop their mathematical models. In high performance applications, it is necessary to determine these parameters that affect driving technique. In this study, when induction motor (IM) was started with continuous and discrete signals, the effects on the motor equivalent circuit parameters of these operating states were investigated. Differential Evolution Algorithm (DEA) and Particle Swarm Optimization (PSO) were used to investigate and determine the changes in parameters and performance. Equivalent circuit parameters were determined on two IMs with $2.2 \mathrm{~kW}$ and $5.5 \mathrm{~kW}$. In this study, it was seen that Differential Evolution Algorithm (DEA) and Particle Swarm Optimization (PSO) determined electrical equivalent circuit parameters of IM with minimum $0,07 \%$ error and minimum $0,28 \%$ error, respectively.
\end{abstract}

Key Words: Induction motor, Particle swarm optimization, Differential evolution algorithm, Equivalent circuit parameters of induction motor, Vector control.

\section{Asenkron Motorların Eşdeğer Devre Parametrelerinin Sezgisel Algoritmalar Kullanılarak Belirlenmesi}

ÖZ: Asenkron motorlar basit, ekonomik ve sağlam olmaları, bakım gerektirmemeleri ve her türlü ortam koşullarında çalışabilmeleri gibi özelliklerinden dolayı, endüstride yaygın olarak kullanılmaktadır. Asenkron motorların doğrusal olmayan modeli ve zamanla değişen parametreleri, matematiksel modelin çıkartılmasını oldukça zorlaştırmaktadır. Yüksek performanslı uygulamalarda, sürme davranışlarını etkileyen bu parametrelerin doğru olarak belirlenmesi gerekmektedir. Bu çalışmada asenkron motor sürekli ve ayrık zamanlı sinyallerle çalıştırıldı̆̆ında, eşdeğer devre parametreleri üzerindeki etkileri incelenmiştir. Parametre ve performans değişimlerinin incelenmesi ve belirlenmesi için Diferansiyel Evrim Algoritması (DEA), Parçalı Sürü Optimizasyonu (PSO) kullanılmıştır. Eşdeğer devre parametreleri $2.2 \mathrm{~kW}$ ve $5.5 \mathrm{~kW}$ gücünde iki asenkron motor üzerinde belirlenmiştir. Yapılan çalışmada asenkron motor elektriksel eşdeğer devre parametrelerinin Diferansiyel Evrim Algoritması ile minimum \%0,07, Parçacık sürü optimizasyonu ile ise minimum $\% 0,29$ hata ile belirlendiği gözlemlenmiştir.

Anahtar Kelimeler: Asenkron motor, Parçacık sürü pptimizasyonu, Diferansiyel evrim algoritması, Asenkron motorun eşdeğer deore parametreleri, Vektör kontrol. 


\section{INTRODUCTION}

Induction motors (IMs) are commonly used in industrial application because of the fact that they are simple, durable, cost-effective and high efficiency. IMs are used with speed control device or by connecting directly to the network. In terms of driving technique, speed control devices can be divided into two as continuous and discrete times. According to these driving techniques, it is important to carry out mathematical modeling of IMs. It is quite difficult to develop mathematical model of IM because of their non-linear model and time varying parameters. In high performance works, it is of great importance to determine these parameters which are affected by driving techniques properly. Therefore, in this study, a heuristic model that can properly determine equivalent circuit parameters of IM operated with different driving techniques was intended to be developed.

Many studies have been carried out so far to determine the parameters of IMs. In a study, researchers have tried to develop a model using the Taguchi method to run a squirrel cage IM effectively. The rated-current of IM was accepted as the quality characteristic. 5 control parameters as rated rotational speed, rated torque, rated phase voltage, efficiency and power factor were chosen to determine the value of quality characteristics. As a result of the regression analyses, it was emphasized that the most important parameters for rated current value were rated rotational speed and rated torque; and the control factors which are less important were rated phase voltage and efficiency (Nutu and Popescu, 2016).

A new method developed in another study provided to determine motor torque components, as well as motor parameters, which are developed by high harmonic components of the current. The validity of the suggested method was verified by comparing motor parameters obtained from unloaded/locked rotor tests performed on a real motor and motor parameters obtained by finite element analysis. In this study, a new approach is presented for IM parameters and torque characteristics obtained from time-harmonic finite element simulations with stationary rotor. This method is also suitable to calculate torque, rotor resistance and inductances like a rotor displacement function (Király and Žarko, 2016).

In another study, genetic algorithm is applied to predict the parameters of IM by means of stator voltage, stator current and rotor rotational speed (Sadasivan and Mammen, 2011), (Kampisios et al., 2008).

To predict the parameters of IM, a linear regression model was also used. This method suggests a recursive least square algorithm by using stator voltage, stator current and rotor rotational speed so as to predict motor parameters in an off-line work (Mohamed et al., 2011).

An Extended Kalman Filter method was also applied to describe the parameters of IM by using 3 phase stator voltage, stator current and rotor rotational speed (Laowanitwattana and Uatrongjit, 2015).

In another study in which Partical Swarm Optimization (PSO) algorithm was used, the changes of the parameters of an IM in steady-state conditions were observed and predicted dynamically. In this study, three phase current, voltage and rotational speed of IM were used as measured values.

In another study, the effect of temperature on motor parameters such as rotor and stator resistance was investigated by means of Two-Stage Single-Flock PSO technique. It is emphasized that the parameters were calculated and the average of normalized estimation error squares was minimized by square root. Simulation results show that the suggested method is at high accuracy and applicability. In this study, a new PSO method is presented to make it easier to predict the parameters of IM under the conditions of temperature rise. This method predicts time varying parameters of IM by taking into account the stator, rotor winding and the changes in the temperature (Tofighi et al., 2013).

In another study, two new methods called Adaptive Neuro Fuzzy Inference System (ANFIS) and Artificial Neural Network (ANN) were presented to predict the parameters of single and double squirrel cage IM. It is stated that 20 IMs with different powers were used for this purpose. Experimental data contain the values of breakaway torque, current, maximum torque, full load, efficiency, active power and reactive power rate. The results obtained from the suggested ANN and ANFIS models were 
compared to experimental data and to each other. According to these results, it is stated that ANFIS model gives more accurate results than ANN model ( Jirdehi and Rezaei, 2014).

In this study, differently from the previous studies, equivalent circuit parameters of an IM running in continuous and discrete time are predicted using PSO and Differential Evolution Algorithm (DEA). The study is comprised of the following sections: Section 1 presents introduction; Section 2 deals with the equivalent circuit of IMs; Section 3 deals with the materials and methods section containing the used heuristic algorithms, test functions and the experimental setup; Section 4 gives the results of the study and Section 5 contains the conclusions.

\section{MATERIAL AND METHOD}

\section{Induction motors}

In IMs, the electrical and mechanical features of 3-phases are equal to each other (Çolak, 2014), (Terzioğlu et al., 2014). For this reason, when the features of one phase are determined in IMs, it means equivalent circuit of a 3-phase IM is also determined. Accordingly, when equivalent circuit of 3-phases IM is formed, it is sufficient that only 1-phase equivalent circuit is determined. In Figure 1, the equivalent circuit of an IM is seen (Çolak, 2014), (Terzioğlu et al., 2014).

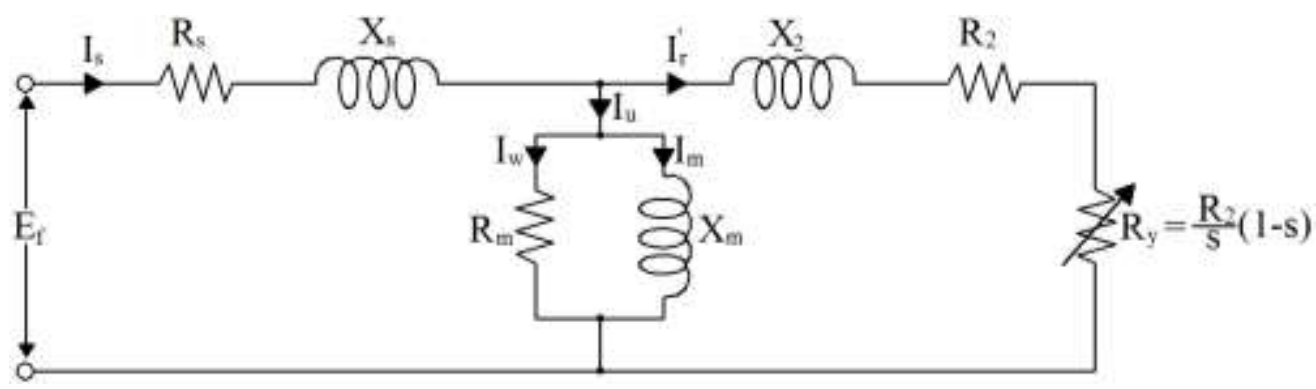

Figure 1. 1-phase equivalent circuit of an IM

The parameters of the equivalent circuit in Figure 1 are described as;

$\mathrm{E}_{\mathrm{f}}$ : A phase voltage value (volt),

$\mathrm{R}_{\mathrm{s}}$ : Internal resistance of stator winding $(\mathrm{Ohm})$,

$\mathrm{X}_{\mathrm{s}}$ : Leakage reactance of stator winding $(\mathrm{Ohm})$,

$I_{s}$ : Current passing through stator circuit (Ampere),

$\mathrm{X}_{2}$ : Equivalent of rotor circuit leakage reactance transferred into rotor circuit (Ohm),

$\mathrm{R}_{2}$ : Equivalent of rotor circuit resistance transferred into stator circuit (Ohm),

$I_{r}$ ': Current passing through rotor circuit (Ampere),

$\mathrm{R}_{\mathrm{m}}$ : Resistance of excitation circuit $(\mathrm{Ohm})$,

$\mathrm{X}_{\mathrm{m}}$ : Excitation reactance in open-circuit operation $(\mathrm{Ohm})$,

$\mathrm{I}_{\mathrm{u}}$ : Current passing through excitation circuit (Ampere),

$I_{m}$ : Magnetizing current (Reactive component of excitation current) (Ampere),

$I_{w}$ : The current through resistor Rm (Active component of excitation current) (Ampere),

$\mathrm{R}_{\mathrm{y}}$ : Electrical resistance of the load in motor shaft in terms of stator terms (Ohm). 
The circuit in Figure 1 is named as real equivalent circuit. To simplify the solution in this circuit, a simplified equivalent circuit which gives similar results to real equivalent circuit results is used (Terzioğlu et al., 2014). In balance 3-phases IM, a simplified equivalent circuit of 1-phase is designed agreeing the conditions below (Terzioğlu et al., 2014).

- Stator winding resistance was kept low to reduce stator copper loss.

- Leakage reactance of stator winding was minimized by reducing average length of wire of each winding.

- To reduce kernel losses (iron loss), thin plates made of low iron loss are used. $\mathrm{R}_{\mathrm{m}}$ is kept high in this way.

- Conductivity of the iron chosen for the plates is high and flux density at the operating point of the motor is kept under the lap robe of magnetization curve. Magnetization reactance is high in that way.

- Simplified equivalent circuit which was obtained when excitation arm was put in the access of equivalent circuit is given in Figure 2 (Arslan et al., 2012).

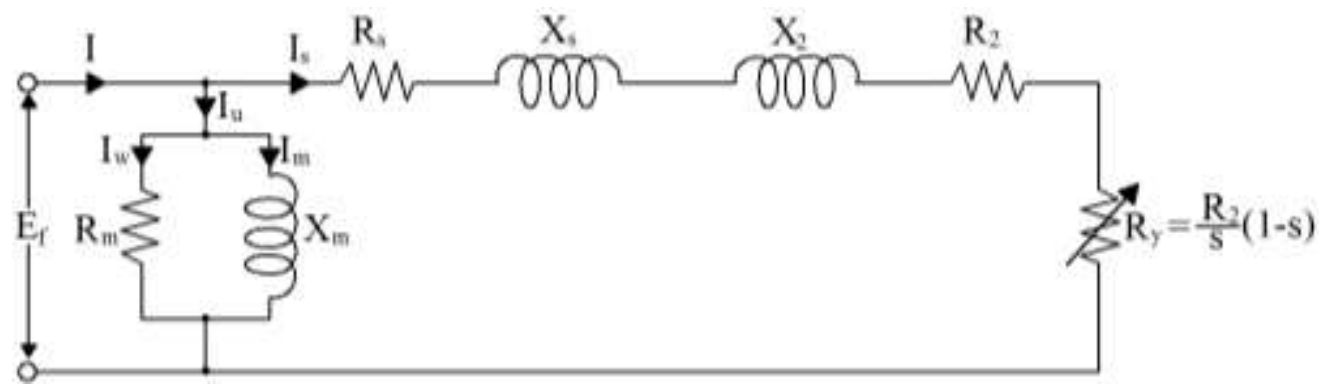

Figure 2. A simplified 1-phase equivalent circuit of IM

Where, I is the current that the motor draws from the network.

\section{Particle swarm optimization (PSO)}

Particle Swarm Optimization (PSO) is a heuristic algorithm developed by James Kennedy and Russell Eberhart in 1995 (Akbulut, 2009). This algorithm is based on social intelligence found in all living things in nature. The behaviors such as the sharing information of people by talking, the using each other to find the direction of birds and the making joint decision for movements of fish swarms are proof of a social existence. Inspired by the using each other to find the direction of birds and the moving together of fish swarms, PSOs have been developed (Eldem, 2014).

PSO shows similarities with evolutionary optimization techniques like Genetic Algorithm (GA) but it does not have evolutionary operators such as crossing and mutation. The solutions called as particles in PSO travel in the problem space by following the best results. The most significant difference of PSO from classical optimization techniques is that it does not need derivative knowledge. PSO can be successfully applied in many areas such as function optimization, fuzzy control system and artificial neural network. When PSO and GA are compared, it can be said that PSO is an algorithm that is easier to realize and less the parameter number to be set. For this reason, PSOs are applied in many areas today (Eldem, 2014). The flow diagram of PSO is seen in Figure 3.

In flow chart, the speed of each particle is arranged by Eq. 1 (Terzioğlu et al., 2013),

$$
v_{i}^{k+1}=w v_{i}^{k}+c_{1} r_{1}\left(\text { pbest }_{i}^{k}-x_{i}^{k}\right)+c_{2} r_{2}\left(\text { gbest }^{k}-x_{i}^{k}\right)
$$

and the position is arranged by Eq. 2, 
$x_{i}^{k+1}=x_{i}^{k}+v_{i}^{k+1}$

where, $\mathrm{c}_{1}$ and $\mathrm{c}_{2}$ are the learning factors, $\mathrm{w}$ is inertia weight, $\mathrm{r}_{1}$ and $\mathrm{r}_{2}$ are the numbers produced randomly in the range $[0,1]$.

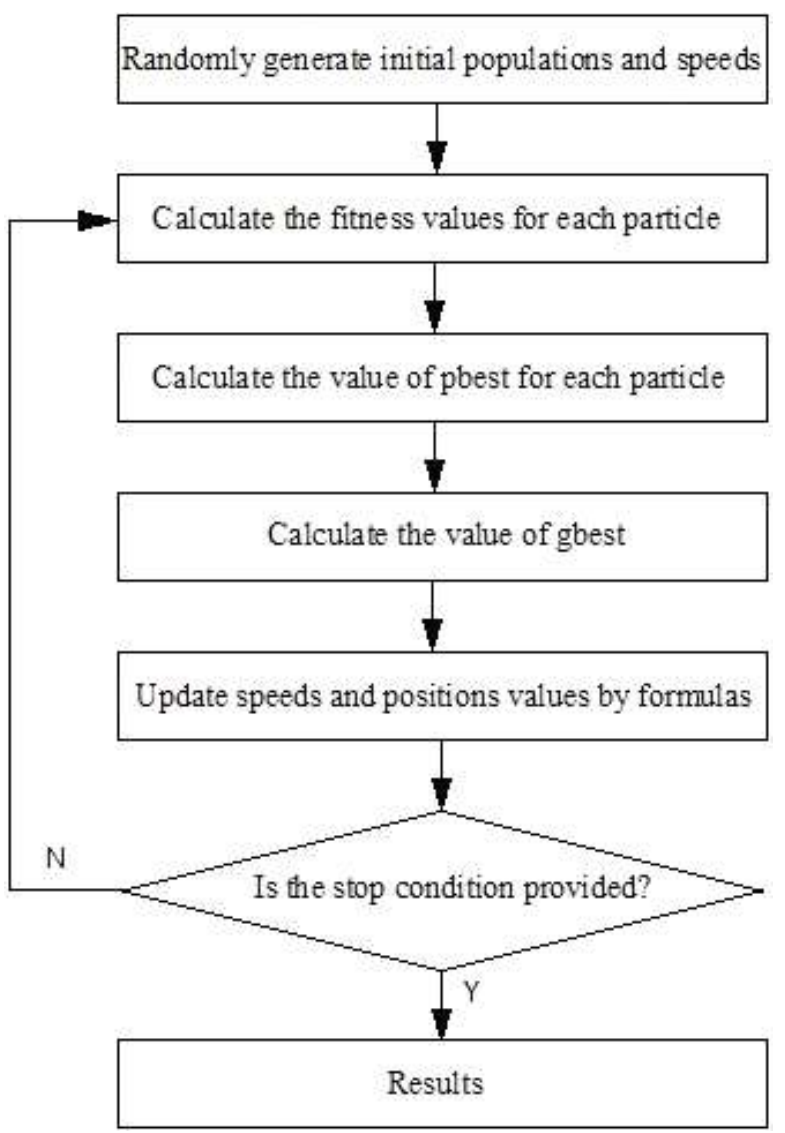

Figure 3. PSO flow chart

\section{Differential evolution algorithm (DEA)}

The techniques based on evolution principles are used to make up the deficiencies of commonly known optimization methods (Arslan et al., 2012), (Price et al., 2006). Recently, the term evolutionary computing representing all of these principles-based techniques has begun to be widely used. GA, evolutionary programming, evolutionary strategies and differential evolution algorithm (DEA) can be given as example to these algorithms (Price et al., 2006), (Storn and Price, 1997). DEA is an algorithm which is both simple and based on the powerful population. Especially, it is used to optimize the functions which are defined in an edited space and contain the design parameters with real precious. Optimization with real parameter composes the important and a broad class of the practical problems encountered in science, engineering and other work environments. Generally, the first operation to be done is to determine a problem-oriented heuristic approach when complex optimization problems are encountered (Özcan and Erol, 2013), (Akkoyunlu and Engin, 2011). These techniques which allow expert knowledge to be added to the design are quite successful when faced with general methods such as the algorithms based upon development. For example, if the objective function is in the form of a linear polynomial, there are successful methods such as Simplex and Karmakar algorithms developed to solve this kind of problem. These methods have the ability to find optimal solutions even if there are hundreds or even thousands of design variables in such problems. If the objective function isn't in the form of a linear polynomial and there aren't problem-oriented methods, generally methods such as Levenberg- 
Marguardt algorithm, Branch and Bound are preferred (Karaboğa, 2014). In Figure 4, schematic diagram of DEA is seen.

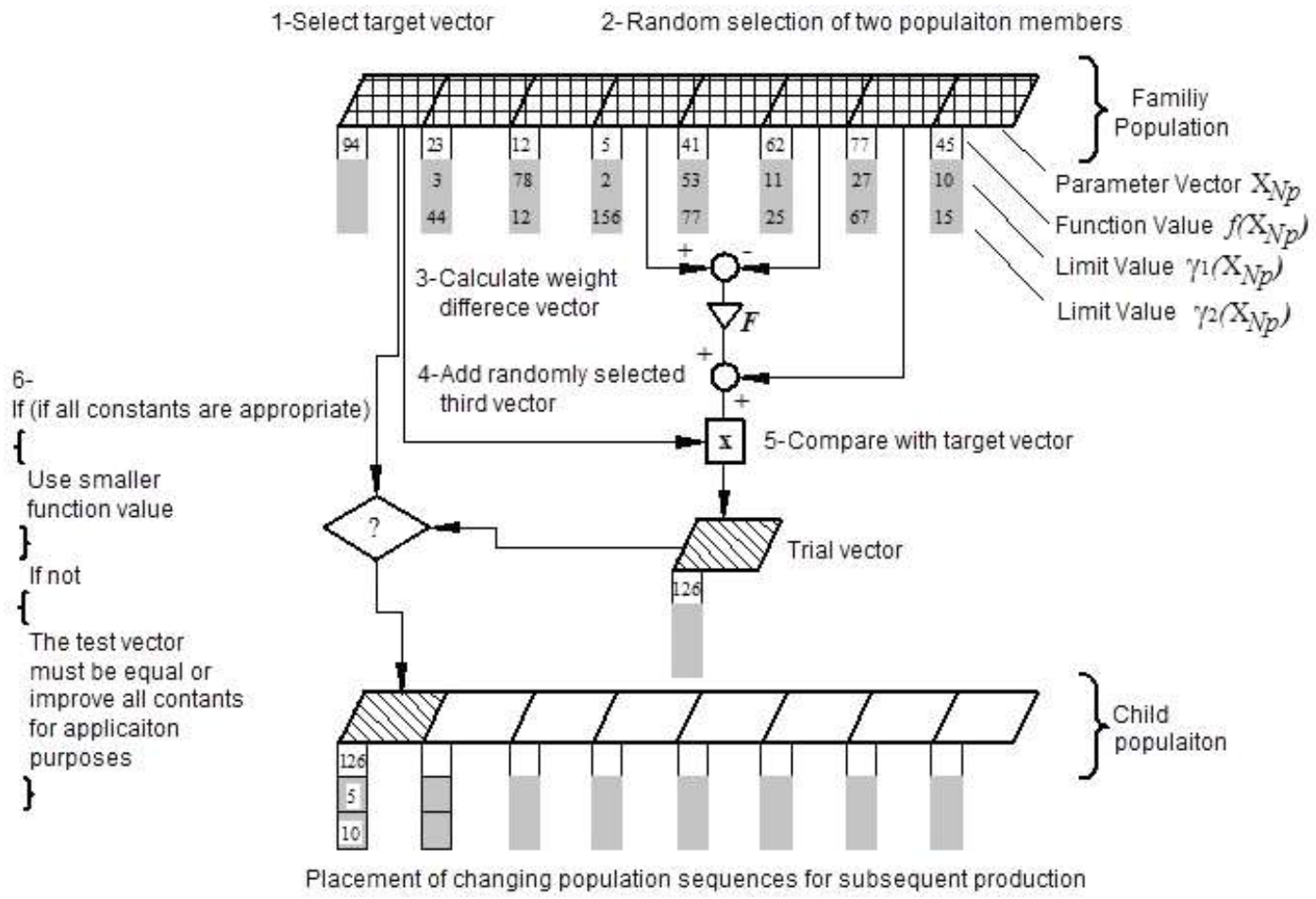

Figure 4. Schematic diagram of DEA (Kiranyaz et al., 2014)

\section{Test functions}

In this study, DEA and PSO were used as heuristic algorithms. The softwares of these algorithms were prepared in Matlab program. To determine the accuracy of the softwares, test functions in Table 1 were used (Kiranyaz et al., 2014).

Table 1. Test Functions

\begin{tabular}{|c|cccc|}
\hline Func. No & Function name & Function & Value (D) & Limits \\
\hline F1 & Sphere & $f_{1}=\sum_{i=1}^{D} x_{i}^{2}$ & 30 & $-100 \leq x_{i} \leq 100$ \\
F2 & Schwefel & $f_{2}=\sum_{i=1}^{D}\left(\sum_{j=1}^{i} x_{j}\right)$ & 30 & $-100 \leq x_{i} \leq 100$ \\
F3 & $\begin{array}{l}\text { Generalized } \\
\text { Rosenbrock }\end{array}$ & $f_{3}=\sum_{i=1}^{D}\left\{100\left(x_{i+1}-x_{i}^{2}\right)^{2}+\left(x_{1}-1\right)^{2}\right\}$ & 30 & $-30 \leq x_{i} \leq 30$ \\
\hline
\end{tabular}

Parameter values of PSO and DEA used to solve the test functions are given in Table 2.

Table 2. Optimization parameters used for heuristic algorithms

\begin{tabular}{|l|l|}
\hline \multicolumn{1}{|c|}{$\begin{array}{c}\text { Particle Swarm Optimization } \\
\text { Algorithms }\end{array}$} & Differential Evolution Algorithm \\
\hline Number of particle $=100$ & Population Size $=100$ \\
Learning Factor $\left(c_{1}\right)=1$ & Crossover rate $=0.80$ \\
Learning Factor $\left(c_{2}\right)=1$ & Scaling Factor $=0.80$ \\
\hline
\end{tabular}


The stop criterias in test functions were determined as " 0 " error rate or the completion of the 1000 iteration. DEA and PSO algorithms were run 20 times for each test function and the average of the obtained results are given in Table 3. As shown in Table 3, DEA gives better results than PSO.

Table 3. Suitability values

\begin{tabular}{|c|cc|cc|}
\hline \multirow{2}{*}{ Function No } & \multicolumn{2}{|c|}{ PSO } & \multicolumn{2}{c|}{ DEA } \\
\cline { 2 - 5 } & Suitability value & $\begin{array}{c}\text { Resulting value } \\
\text { (result) }\end{array}$ & $\begin{array}{c}\text { Suitability } \\
\text { value }\end{array}$ & $\begin{array}{c}\text { Resulting value } \\
\text { (result) }\end{array}$ \\
\hline F1 & $1.58069 \mathrm{E}-07$ & 0 & $4.1628 \mathrm{E}-215$ & 0 \\
F2 & 0.952750131 & 0 & $2.28114 \mathrm{E}-08$ & 0 \\
F3 & 0.005127272 & 0 & 0 & 0 \\
\hline
\end{tabular}

\section{Modeling accuracy}

Accuracy is a value which indicates how close the calculated value is to the measured value. For each data value, it is necessary to determine the error between the measured value (reference) and the predicted value. Measured values were defined by $M P R=\left(R s r, R_{2} r, X_{s r}, X_{2} r, X m r\right)$ vector and predicted values were defined by $\mathrm{MPP}=\left(\mathrm{Rsp}_{\mathrm{s}} \mathrm{R}_{2} \mathrm{p}, \mathrm{X}_{\mathrm{sp}}, \mathrm{X}_{2 \mathrm{p}}, \mathrm{Xmp}_{\mathrm{mp}}\right)$ vector. The test was repeated 10 times, so the value which was predicted $i$. times was defined as,

$\mathrm{MPP}_{\mathrm{i}}=\left(\mathrm{Rsp}_{\mathrm{i}}, \mathrm{R}_{2} \mathrm{p}_{\mathrm{i}}, \mathrm{X}_{\mathrm{s}} \mathrm{p}_{\mathrm{i}}, \mathrm{X}_{2} \mathrm{p}_{\mathrm{i}}, \mathrm{Xmp}_{\mathrm{i}}\right), \quad 1 \leq \mathrm{i} \leq 10$

Average percentage error of each variant is calculated using Eq. (3).

$\Delta_{\mathrm{n}}=\frac{1}{10} * \sum_{i=1}^{10}\left(\frac{\left|\mathrm{MPR}_{\mathrm{n}}-\mathrm{MPP}_{\mathrm{n}}^{\mathrm{i}}\right|}{\mathrm{MPR}_{\mathrm{n}}} * 100\right), 1 \leq \mathrm{n} \leq 5$

In Eq. (3), i refers to repetition number and $\mathrm{n}$ index refers to the variable number in MPP vector, respectively. 


\section{Experimental setup}

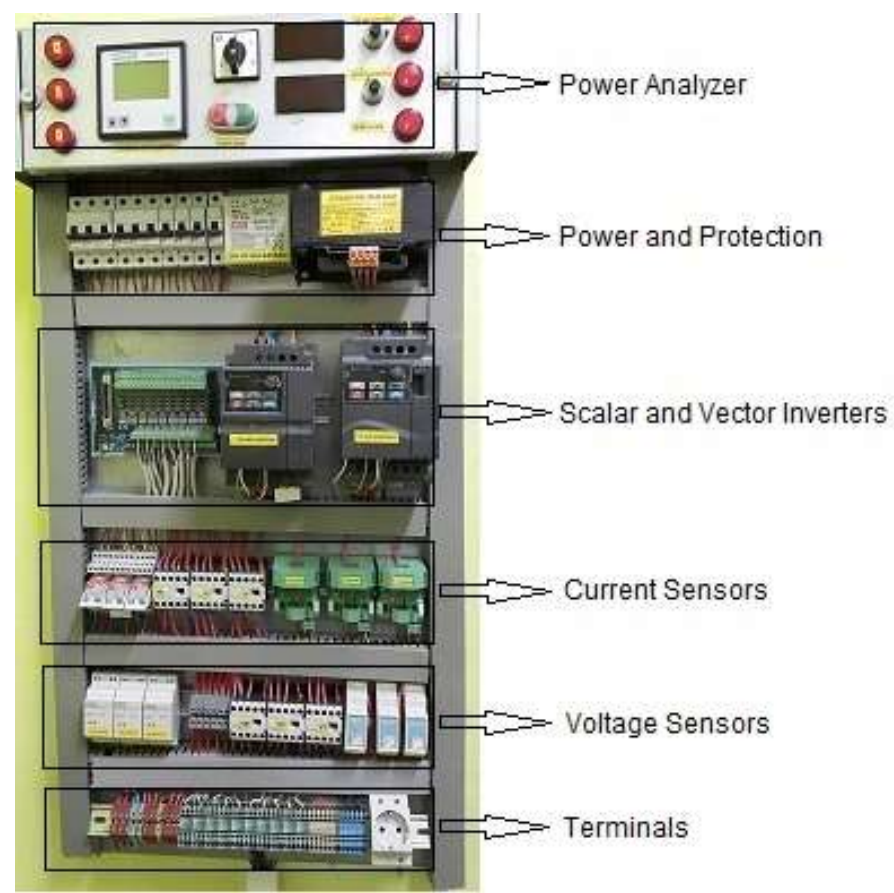

Figure 5. Inverter and sensor connection board of IM

IMs are used in various applications in industry with different control methods. In this study, IMs were run by using continuous and vector controlled speed controller devices. The control board performed for this study is seen in Figure 5. In the board, there is an isolation transformer, 3 pieces Phoenix current sensors, 3 pieces Klemsan tension sensors, Siemens power analyzer and board connection of data processing card. In this study, 2 pieces IMs whose attributes were given in Table 4 were used.

Table 4. Catalogue information of the IMs

\begin{tabular}{|l|ll|}
\hline Attributes & IM1 & IM2 \\
\hline Power (kW) & $2.2 \mathrm{~kW}$ & $5.5 \mathrm{~kW}$ \\
Tension (V) & $380 \mathrm{~V}-\lambda$ & $380 \mathrm{~V}-\Delta$ \\
Current(A) & $5 \mathrm{~A}$ & $11.2 \mathrm{~A}$ \\
Rpm (d/dk) & $1420 \mathrm{~d} / \mathrm{dk}$ & $1435 \mathrm{~d} / \mathrm{dk}$ \\
Moment (Nm) & $14.6 \mathrm{Nm}$ & $35.9 \mathrm{Nm}$ \\
\hline
\end{tabular}

\section{RESULT AND DISCUSSION}

In this study, different methods were used to determine the electrical parameters of IMs which were run with different driving techniques, the results and the differences were examined.

For this purpose, firstly using the test method, motor parameters of IMs whose attributes were given in Table 4 were determined. Test method consists of three tests as open-circuit run, locked rotor and stator winding resistance. The tests were performed for two different running conditions of IMs such as running with discrete time speed control device and running with continuous time speed control device. Equivalent circuit parameters of IMs were calculated using the motor data obtained from these running conditions. Equivalent circuit parameters $M P R=\left(R_{s r}, R_{2 r}, X_{s r}, X_{2 r}, X_{m r}\right)$ which were calculated depending upon the data obtained from the tests on IMs were accepted as reference values.

Secondly, using motor data obtained from the tests, equivalent circuit parameters of IMs $M P P=\left(R_{s p}\right.$, $\mathrm{R}_{2 \mathrm{p}}, \mathrm{X}_{\mathrm{sp}}, \mathrm{X}_{2 \mathrm{p}}, \mathrm{X}_{\mathrm{mp}}$ ) were tried to be predicted by PSO and DEA. 


\section{Determination of equivalent circuit parameters of IMs by using test method}

For determining the IM data by the test method, the tests were carried out for open-circuit run, locked rotor and measurement of stator winding resistance. In accordance with IEEE standard test procedure, these tests were performed for two different running situations as running with discrete time speed control device and with continuous time speed control device. For calculating the effective resistance $\mathrm{R}_{\mathrm{s}}$ of 1-phase of the IM, the direct current resistance obtained by measuring of stator winding resistance was multiplied by 1.2 (Çolak, 2014).

When the IM was run with discrete time speed control device and with continuous time speed control device, the obtained test results are given in Table 5.

Table 5. Test results of IMs run with different driving techniques

\begin{tabular}{|l|ll|ll|l|}
\hline \multirow{2}{*}{ IMs } & \multicolumn{2}{|c|}{ Continuous Time } & \multicolumn{2}{c|}{ Discrete Time } & \\
\cline { 2 - 6 } & Open-circuit & Locked rotor & Open-circuit & Locked rotor & Winding resistance \\
\hline \multirow{4}{*}{ IM1 } & $\mathrm{V} 0=380 \mathrm{~V}$ & $\mathrm{Vk}=100 \mathrm{~V}$ & $\mathrm{~V} 0=380 \mathrm{~V}$ & $\mathrm{Vk}=100 \mathrm{~V}$ & $\mathrm{Rd}=3.5 \Omega$ \\
& $\mathrm{I} 0=3.2 \mathrm{~A}$ & $\mathrm{Ik}=5.8 \mathrm{~A}$ & $\mathrm{I} 0=3 \mathrm{~A}$ & $\mathrm{Ik}=6 \mathrm{~A}$ & $\mathrm{Rs}=4.55 \Omega$ \\
& $\mathrm{P} 0=320 \mathrm{~W}$ & $\mathrm{Pk}=800 \mathrm{~W}$ & $\mathrm{P} 0=380 \mathrm{~W}$ & $\mathrm{Pk}=900 \mathrm{~W}$ & \\
& $\mathrm{~V} 0=380 \mathrm{~V}$ & $\mathrm{Vk}=90 \mathrm{~V}$ & $\mathrm{~V} 0=380 \mathrm{~V}$ & $\mathrm{Vk}=90 \mathrm{~V}$ & $\mathrm{Rd}=2.64 \Omega$ \\
IM2 & $\mathrm{I}=4.9 \mathrm{~A}$ & $\mathrm{Ik}=9.8 \mathrm{~A}$ & $\mathrm{I}=4.8 \mathrm{~A}$ & $\mathrm{Ik}=9.8 \mathrm{~A}$ & $\mathrm{Rs}=5,14 \Omega$ \\
& $\mathrm{P} 0=370 \mathrm{~W}$ & $\mathrm{Pk}=850 \mathrm{~W}$ & $\mathrm{P} 0=450 \mathrm{~W}$ & $\mathrm{Pk}=900 \mathrm{~W}$ & \\
\hline
\end{tabular}

For running with discrete time speed control device and with continuous time speed control device, the equivalent circuit parameters which were calculated by using the values in Table 5 are given in Table 6.

Table 6. The equivalent circuit parameters of IMs which are run with different driving techniques

\begin{tabular}{|c|cc|cc|}
\hline \multirow{2}{*}{ Parameters } & \multicolumn{2}{|c|}{ Continuous Time Speed Cont. } & \multicolumn{2}{c|}{ Discrete Time Speed Cont. } \\
\cline { 2 - 5 } & IM1 & IM2 & IM1 & IM2 \\
\hline $\mathbf{R}_{\mathbf{s r}}$ & $4.55 \Omega$ & $5.14 \Omega$ & $4.55 \Omega$ & $5.14 \Omega$ \\
$\mathbf{R}_{2 \mathrm{r}}$ & $3,38 \Omega$ & $3.7 \Omega$ & $3.78 \Omega$ & $4.22 \Omega$ \\
$\mathbf{X}_{\mathrm{sr}}$ & $3.01 \Omega$ & $6.6 \Omega$ & $2.4 \Omega$ & $6.43 \Omega$ \\
$\mathbf{X}_{\mathbf{2 r}}$ & $3.01 \Omega$ & $6.6 \Omega$ & $2.4 \Omega$ & $6.43 \Omega$ \\
$\mathbf{R}_{\mathrm{mr}}$ & $801.23 \Omega$ & $1758.142 \Omega$ & $561.54 \Omega$ & $1307.22 \Omega$ \\
$\mathbf{X}_{\mathrm{mr}}$ & $68.81 \Omega$ & $134.72 \Omega$ & $73.75 \Omega$ & $137.88 \Omega$ \\
\hline
\end{tabular}

Determination of equivalent circuit parameters of IMs by using particle swarm optimization and differential evolution algorithm

In DEA and PSO algorithms, moment equations of IMs were used as an objective function (Arslan et al., 2012). These functions consist of locked rotor, overturning and full load moments. Error functions were obtained by using Eq. 4, 5 and 6. Suitability function was calculated as sum of square error with Eq. 7 (Arslan et al., 2012).

$T_{1}=\frac{\mathrm{V}_{\mathrm{s}} \frac{\mathrm{R}_{2}}{\mathrm{~s}}}{\omega_{\mathrm{s}}\left[\left(\mathrm{R}_{\mathrm{s}}+\mathrm{R}_{2} / \mathrm{s}\right)^{2}+\left(\mathrm{X}_{\mathrm{s}}+\mathrm{X}_{2}\right)^{2}\right]}-T_{n}$ 


$$
\begin{aligned}
& T_{2}=\frac{\mathrm{V}_{\mathrm{s}}^{2} \mathrm{R}_{2}}{\omega_{\mathrm{s}}\left[\left(\mathrm{R}_{\mathrm{s}}+\mathrm{R}_{2}\right)^{2}+\left(\mathrm{X}_{\mathrm{s}}+\mathrm{X}_{2}\right)^{2}\right]}-T_{k} \\
& T_{3}=\frac{\mathrm{V}_{\mathrm{s}}^{2}}{2 \omega_{\mathrm{s}}\left[\mathrm{R}_{\mathrm{s}}+\sqrt{\mathrm{R}_{\mathrm{s}}^{2}+\left(\mathrm{X}_{\mathrm{s}}+\mathrm{X}_{2}\right)^{2}}\right]}-T_{d}
\end{aligned}
$$

The terms used in the equalities above are given below.

$\mathrm{T}_{\mathrm{n}}$ : Nominal moment

$\mathrm{T}_{\mathrm{k}}$ : Start momentum

$\mathrm{T}_{\mathrm{d}}$ : Overturning momentum

$T_{1} \quad$ : Error value in full road moment of rotation

$T_{2}$ : Error value in start momentum

$T_{3} \quad$ : Error value in overturning moment

In PSO and DEA, suitability function is the sum of squares of moment error function and algorithms aim to minimize the error value.

Suitability Function $=F_{1}^{2}+F_{2}^{2}+F_{3}^{2}$

Table 7. \% maximum and minimum error values of equivalent circuit parameters for different running

\begin{tabular}{|c|c|c|c|c|c|c|c|c|c|}
\hline \multirow{3}{*}{$\begin{array}{l}\text { Equivalent } \\
\text { Circuit } \\
\text { Parameters }\end{array}$} & \multirow{3}{*}{$\begin{array}{l}\text { Max. and } \\
\text { Min. Error } \\
\text { Values }\end{array}$} & \multicolumn{4}{|c|}{$\begin{array}{l}\text { Continuous Time } \\
\text { Speed Control }\end{array}$} & \multicolumn{4}{|c|}{$\begin{array}{l}\text { Discrete Time } \\
\text { Speed Control }\end{array}$} \\
\hline & & \multicolumn{2}{|c|}{ IM1 } & \multicolumn{2}{|c|}{ IM2 } & \multicolumn{2}{|c|}{ IM1 } & \multicolumn{2}{|c|}{ IM2 } \\
\hline & & PSO & DEA & PSO & DEA & PSO & DEA & PSO & DEA \\
\hline \multirow{2}{*}{$\mathbf{R}_{\mathrm{s}}$} & $\Delta_{1 \max }$ & 3,18 & 0,47 & 3,85 & 1,19 & 8,9 & 2,32 & 4,95 & 1,97 \\
\hline & $\Delta 1_{\text {min }}$ & 2,84 & 0,41 & 3,65 & 1,15 & 8,65 & 2,12 & 4,82 & 1,92 \\
\hline \multirow{2}{*}{$\mathbf{R}_{\mathbf{2}}$} & $\Delta_{2 \max }$ & 5,85 & 1,23 & 4,38 & 0,3 & 6,48 & 2,47 & 3,86 & 1,26 \\
\hline & $\Delta_{2 \min }$ & 5,38 & 1,14 & 4,26 & 0,2 & 6,24 & 2,3 & 3,52 & 1,04 \\
\hline \multirow{2}{*}{$X_{s}$} & $\Delta_{3 \max }$ & 3,74 & 1,73 & 0,83 & 0,48 & 7,16 & 2,12 & 1,33 & 1,11 \\
\hline & $\Delta_{3 \min }$ & 3,63 & 1,64 & 0,7 & 0,43 & 6,97 & 2,05 & 1,2 & 1,06 \\
\hline \multirow{2}{*}{$X_{2}$} & $\Delta_{4 \max }$ & 1,68 & 1,69 & 3,24 & 1,39 & 3,79 & 2,1 & 2,85 & 1,88 \\
\hline & $\Delta_{4 \min }$ & 1,64 & 1,65 & 3,02 & 1,34 & 3,71 & 2,06 & 2,72 & 1,86 \\
\hline \multirow{2}{*}{$X_{m}$} & $\Delta 5 \max$ & 0,44 & 0,23 & 0,29 & 0,08 & 0,37 & 0,31 & 0,3 & 0,09 \\
\hline & $\Delta_{5 \min }$ & 0,41 & 0,2 & 0,27 & 0,06 & 0,33 & 0,29 & 0,28 & 0,07 \\
\hline
\end{tabular}
conditions 
Table 8. \% error values of equivalent circuit parameters for different running conditions

\begin{tabular}{|c|c|c|c|c|c|c|c|c|}
\hline \multirow[t]{3}{*}{ Parameters } & \multicolumn{4}{|c|}{$\begin{array}{l}\text { Continuous Time } \\
\text { Speed Control }\end{array}$} & \multicolumn{4}{|c|}{$\begin{array}{l}\text { Discrete Time } \\
\text { Speed Control }\end{array}$} \\
\hline & \multicolumn{2}{|c|}{ IM1 } & \multicolumn{2}{|c|}{ IM2 } & \multicolumn{2}{|c|}{ IM1 } & \multicolumn{2}{|c|}{ IM2 } \\
\hline & PSO & DEA & PSO & DEA & PSO & DEA & PSO & DEA \\
\hline $\mathbf{R}_{\mathrm{sr}}$ & 4,55 & 4,55 & 5,14 & 5,14 & 4,55 & 4,55 & 5,14 & 5,14 \\
\hline $\mathbf{R}_{\text {sp }}$ & 4,41 & 4,57 & 4,95 & 5,08 & 4,95 & 4,65 & 4,89 & 5,04 \\
\hline$\Delta_{1}$ & 3,08 & 0,44 & 3,70 & 1,17 & 8,79 & 2,2 & 4,86 & 1,95 \\
\hline $\mathbf{R}_{2 \mathrm{r}}$ & 3,38 & 3,38 & 3,70 & 3,70 & 3,78 & 3,78 & 4,22 & 4,22 \\
\hline $\mathbf{R}_{2 \mathrm{p}}$ & 3,57 & 3,42 & 3,54 & 3,69 & 3,54 & 3,69 & 4,38 & 4,27 \\
\hline$\Delta_{2}$ & 5,62 & 1,18 & 4,32 & 0,27 & 6,35 & 2,38 & 3,79 & 1,18 \\
\hline $\mathbf{X}_{\mathrm{sr}}$ & 3,01 & 3,01 & 6,60 & 6,60 & 2,4 & 2,4 & 6,43 & 6,43 \\
\hline $\mathbf{X}_{\mathrm{sp}}$ & 2,90 & 2,96 & 6,55 & 6,63 & 2,57 & 2,35 & 6,51 & 6,5 \\
\hline$\Delta_{3}$ & 3,65 & 1,66 & 0,76 & 0,45 & 7,08 & 2,08 & 1,24 & 1,09 \\
\hline$X_{2 r}$ & 3,01 & 3,01 & 6,60 & 6,60 & 2,4 & 2,4 & 6,43 & 6,43 \\
\hline$X_{2 p}$ & 2,96 & 2,96 & 6,39 & 6,69 & 2,49 & 2,45 & 6,61 & 6,55 \\
\hline$\Delta_{4}$ & 1,66 & 1,66 & 3,18 & 1,36 & 3,75 & 2,08 & 2,80 & 1,87 \\
\hline$X_{\mathrm{mr}}$ & 68,81 & 68,81 & 134,72 & 134,72 & 73,75 & 73,75 & 137,88 & 137,88 \\
\hline$X_{\mathrm{mp}}$ & 68,52 & 68,66 & 134,34 & 134,62 & 73,53 & 73,53 & 137,48 & 137,77 \\
\hline$\Delta_{5}$ & 0,42 & 0,22 & 0,28 & 0,07 & 0,34 & 0,30 & 0,29 & 0,08 \\
\hline
\end{tabular}

For DEA and PSO, the software of objective function determined in the problem was prepared in Matlab program. In the software, the calculations performed by using data obtained from experimental method were taken into account to determine the limit values of motor parameters $M P P=\left(R_{s p}, R_{2 p}, X_{s p}\right.$, $\mathrm{X}_{2 \mathrm{p}}, \mathrm{X}_{\mathrm{mp}}$ ). The equivalent circuit parameters were calculated through PSO and DEA for running conditions of IMs with discrete time speed control device and with continuous time speed control device.

For two running conditions performed on IMs, algorithms were tested 10 times and the values obtained for each test were recorded. Then, the equivalent circuit parameters were calculated by using these values. The error value was calculated by using Eq. 3 for each value and it was found by taking error average of 10 tests.

The maximum and minimum error values obtained as a result of the performed tests are given in Table 7. These values show that the algorithms run in stable and the sufficient error range. The average of the values obtained from continuous time speed control device and discrete time speed control device of IM1 and IM2 is given in Table 8.

As shown in the Table 8, the data obtained from PSO and DEA include acceptable values for each running condition. As it is seen in Table 8, DEA algorithm gives better results than PSO in the running both with continuous time speed control device and discrete time speed control device.

Taking into account the determined equivalent circuit parameters of IMs, total error value for all motor parameters was calculated by using Eq. 8 and these values were given in Table 9 .

$$
\Delta=\frac{1}{5} * \sum_{n=1}^{5}\left(\Delta_{\mathrm{n}}\right)
$$


Table 9. Total \% error values of DEA and PSO for different running conditions

\begin{tabular}{|cccc|cccc|}
\hline \multicolumn{3}{|c|}{$\begin{array}{c}\text { Continuous Time } \\
\text { Speed Control }\end{array}$} & \multicolumn{4}{c|}{$\begin{array}{c}\text { Discrete Time } \\
\text { Speed Control }\end{array}$} \\
\hline \multicolumn{2}{|c}{ IM1 } & \multicolumn{2}{c|}{ IM2 } & \multicolumn{2}{c|}{ IM1 } & \multicolumn{2}{c|}{ IM2 } \\
\hline PSO & DEA & PSO & DEA & PSO & DEA & PSO & DEA \\
\hline 2,886 & 1,032 & 2,448 & 0,664 & 5,262 & 1,808 & 2,596 & 1,234 \\
\hline
\end{tabular}

As it is seen in Table 9, DEA gives the best results both in all running conditions and in different IMs. DEA reduces the total \% error value which indicates the success of the algorithm to $0,664 \%$. However, PSO reveals lower performance than DEA with 2,448 \% of the total \% error value. Also, as shown in Table 9, DAE and PSO produce more errors in discrete time running condition than in continuous time running condition.

\section{CONCLUSION}

IMs are run by different speed control methods according to their places of use in industry. In this study, continuous time and discrete time speed control devices which were commonly used in the controls of IMs were applied. The effects of different speed control devices on motor parameters were investigated and heuristic algorithms were run in continuous and discrete time. In this way, the performances of heuristic algorithms in determination equivalent circuit parameters of IMs were investigated. The experimental studies were performed on 2,2 kW and 5,5 kW IMs.

As a result of this study, it was seen that DEA runs with minimum $0,07 \%$ error in continuous times running conditions and PSO runs with minimum 0,28 error in determination of equivalent circuit parameters of IMs; on the other hand, in discrete time running conditions DEA runs minimum 0,08\% error and PSO runs with minimum $0,29 \%$ error. In this study, it was discovered that DEA gives better results than PSO. Moreover, it was seen that DEA and PSO produce better results in continuous time running than in discrete time running.

\section{ACKNOWLEDGE}

The authors are grateful for the financial support provided by Selcuk University Research Foundation under the Research Project No 14401035.

\section{REFERENCES}

Akbulut, İ., 2009, Parçacık Sürü Optimizasyonu ile Anten Tasarımı, Yüksek Lisans Tezi, İstanbul Teknik Üniversitesi, Bilişim Enstitüsü, İstanbul.

Akkoyunlu, M.C., Engin, O., 2011, "Kesikli Harmoni Arama Algoritması Ile Optimizasyon Problemlerinin Çözümü: Literatür Araştırması", J. Fac.Eng.Arch. Selcuk Univ., Vol. 26, No.4, pp. 140-148.

Arslan, M., Çunkaş, M., Sağ, T., 2012, "Determination of Induction Motor Parameters with Differential Evolution Algorithm", Neural Computing and Applications, Vol. 21, No.8, pp. 1995-2004.

Çolak, İ., Elektrik Makinaları - 2, 2014, Seçkin Yayıncllık, Eylül 2014, 3. Baskı, 352 Sayfa.

Eldem, H., 2014, Karınca Koloni Optimizasyonu (KKO) ve Parçacık Sürü Optimizasyonu (PSO) Algortimaları Temelli Bir Hiyerarşik Yaklaşım Geliştirilmesi, Yüksek Lisans Tezi, Selçuk Üniversitesi, Fen Bilimleri Enstitüsü, Konya.

Jirdehi, M.A., Rezaei, A., 2014, "Parameters Estimation of Squirrel-cage Induction Motors Using ANN and ANFIS", Alexandria Engineering Journal, Vol. 55, No.1, pp. 357-368. 
Kampisios, K., Zanchetta, P., Gerada, C., Trentin, A., 2008, "Identification of Induction Machine Electrical Parameters using Genetic Algorithms Optimization", Industry Applications Society Annual Meeting IAS '08. IEEE, Edmonton, Alberta, Canada, 1-7, 5-9 October 2008.

Karaboğa, D., 2014, Yapay Zeka Optimizasyon Algoritmalarl, Nobel Yayıncilık,

Király, I., Žarko, D., 2016, "Extended space Vector Method for Calculation of Induction Motor Parameters", Electric Power Components and Systems, Vol. 44, No. 8, pp. 928-940.

Kiranyaz, S., Ince T., Gabbouj M., 2014, "Multidimensional Particle Swarm Optimization for Machine Learning and Pattern Recognition", Adaptation, Learning, and Optimization, Springer-Verlag Berlin Heidelberg, 15.

Laowanitwattana, J., Uatrongjit, S.,2015, "Induction Motor States and Parameters Estimation, using Extended Kalman Filter with Reduced Number of Measurements". Electrical Machines and Systems (ICEMS), 18th Inter. Conf. on. , Pattaya City, Thailand, pp. 1631-1635, 25-28 October 2015.

Mohamed, Y.S., Hasaneen, B.M., Elbaset, A.A., Hussein, A.E., 2011, "Recursive Least Square Algorithm for Estimating Parameters of an Induction Motor", Journal of Eng. Sciences, Assiut Uni., Vol. 39, No. 1, pp. 87-98.

Nutu, C.S., Popescu, M.O., 2016, "Applying Taguchi Method for Control Parameters of an Induction Motor", University Politehnica Of Bucharest Scientific Bulletin Series C-Electrical Engineering And Computer Science, Vol. 78, No.2, pp. 203-208.

Özcan, E.C., Erol, S., 2013, " Türkiye'de Elektrik Üretim Planlaması Için Çok Amaçlı Bir Karışık Tam Sayılı Doğrusal Programlama Modeli", Selcuk Univ. J. Eng. Sci. Tech., Vol. 1, No.1, pp. 41-54.

Price, K., Storn, R.M., Lampinen, J.A., 2006, "Differential Evolution: A Practical Approach to Global Optimization", Springer; 2005 edition (December 22, 2005), 539 pages.

Sadasivan, J., Mammen, O., 2011, "Genetic Algorithm Based Parameter Identification of Three Phase Induction Motors", Reproduction, Vol. 31, No. 10, pp. 51-56.

Storn, R., Price, K., 1997, "Differential Evolution-a Simple and Efficient Heuristic for Global Optimization over Continuous Spaces", Journal of Global Optimization, Vol. 11, No.4, pp. 341359.

Terzioğlu, H., Herdem, S., Bal, G., 2013, " The Minimization of Torque Ripples of Segmental Type Switched Reluctance Motor by Particle Swarm Optimization", International Journal of Intelligent Systems and Applications in Engineering, Vol. 4, pp. 199-203.

Terzioğlu, H., Kazan, F.A., Arslan, M., Asenkron ve Senkron Makineler, Mesleki Akademi, 2014, p.246.

Tofighi, E.M., Mahdizadeh, A., Feyzi, M.R., 2013, "Online Estimation of Induction Motor Parameters using a Modified Particle Swarm Optimization Technique", Industrial Electronics Society, IECON 2013 - 39th Annual Conference of the IEEE, Vienna, Austria, pp. 3645-3650, 10-14 November 2013. 